\title{
Temperature and $\mathrm{KClO}_{4}$-induced metamorphosis in the sea lamprey (Petromyzon marinus)
}

\author{
Richard G. Manzon 1, John H. Youson* \\ Department of Zoology and Division of Life Sciences, University of Toronto at Scarborough, 1265 Military Trail, Toronto, Ont., Canada, \\ M1C $1 A 4$
}

Received 25 February 1999; received in revised form 13 August 1999; accepted 16 August 1999

\begin{abstract}
Larval sea lampreys (Petromyzon marinus) were exposed to either a warm $\left(18^{\circ} \mathrm{C}\right)$ or a cold $\left(3^{\circ} \mathrm{C}\right)$ water temperature and either with (treated) or without (untreated) the presence of potassium perchlorate $\left(\mathrm{KClO}_{4}\right)$. After 23 weeks, larvae were examined for signs of metamorphosis and serum samples were collected to assay thyroxine $\left(\mathrm{T}_{4}\right)$ and 3,5,3'-triiodothyronine $\left(\mathrm{T}_{3}\right)$ concentrations. Water temperature did not significantly affect serum $\mathrm{T}_{4}$ or $\mathrm{T}_{3}$ concentrations in untreated larvae and no metamorphosis occurred in these groups. Serum $\mathrm{T}_{4}$ concentrations were not significantly different between the two temperature groups treated with $\mathrm{KClO}_{4}$. However, serum $\mathrm{T}_{3}$ concentrations were significantly higher in the cold water, $\mathrm{KClO}_{4}$-treated larvae $(5.4 \mathrm{nmol} / \mathrm{l})$ than in the warm water, $\mathrm{KClO}_{4}$-treated larvae $(1.2 \mathrm{nmol} / 1) . \mathrm{KClO}_{4}$ treatment at a warm water temperature induced metamorphosis in all larvae and resulted in serum $T_{4}$ and $T_{3}$ concentrations which were 66 and $95 \%$ lower, respectively, than untreated larvae in warm water. Despite having significantly lower serum $\mathrm{T}_{4}$ and $\mathrm{T}_{3}$ concentrations (73 and $80 \%$, respectively) than untreated cold water larvae, metamorphosis was not observed in cold water, $\mathrm{KClO}_{4}$-treated larvae. The results of this study indicate that warm water is a requirement for the successful induction of metamorphosis with $\mathrm{KClO}_{4}$, and provide further evidence of water temperature as an important factor in the metamorphosis of lampreys. (C) 1999 Elsevier Science Inc. All rights reserved.
\end{abstract}

Keywords: Petromyzontiformes; Lamprey; Metamorphosis; Temperature; Potassium perchlorate; Thyroxine; Triiodothyronine

\section{Introduction}

The life cycle of the sea lamprey (Petromyzon marinus) includes a sedentary, filter-feeding, larval period lasting 3-7 years and a true metamorphosis in which larvae undergo many morphological and physiological changes in preparation for a free-swimming, parasitic, juvenile phase $[21,22]$. Numerous studies (see for example Refs. $[23,24]$ ) have investigated the environmental and physiological factors which potentially influence the onset, rate, and incidence of metamorphosis in lampreys. Included among these factors are temperature, lipid reserves, and thyroid hormones (TH).

Temperature is the predominant environmental factor influencing metamorphosis in lampreys. Studies

\footnotetext{
* Corresponding author: Tel.: + 1-416-287-7397; fax: + 1-416-2877642 .

E-mail addresses: richard.manzon@scar.utoronto.ca (R.G. Manzon),youson@scar.utoronto.ca (J.H. Youson)

${ }^{1}$ Tel.: + 1-416-287-7441; fax: + 1-416-287-7642.
}

have indicated that temperature can affect the rate, the time of onset, and the incidence of spontaneous metamorphosis in larval sea lampreys $[13,16,17,26]$. In the aforementioned studies, warm water temperatures $\left(21^{\circ} \mathrm{C}\right)$ were more favourable for metamorphosis than cool water temperatures $\left(13^{\circ} \mathrm{C}\right)$.

Throughout the larval growth phase in sea lampreys, serum thyroxine $\left(\mathrm{T}_{4}\right)$ and 3,5,3'-triiodothyronine $\left(\mathrm{T}_{3}\right)$ concentrations gradually rise and reach their peak just prior to the onset of metamorphosis [27]. Subsequent to a peak in serum $\mathrm{TH}$ concentrations and concomitant with early metamorphic change, serum $\mathrm{TH}$ concentrations decline rapidly $[11,20,27]$. The significance of this peak and decline is not fully understood, but several experiments suggest that they are keys to metamorphosis. Treatment of larval sea lampreys (including larvae smaller than the minimum size required for spontaneous metamorphosis) with potassium perchlorate $\left(\mathrm{KClO}_{4}\right)$ depressed serum $\mathrm{TH}$ concentrations and induced metamorphosis at a time of year when sponta- 
neous metamorphosis does not occur [6,28]. Furthermore, $\mathrm{KClO}_{4}$-induced metamorphosis can be blocked with exogenous $T_{4}$ or $T_{3}$ treatments [14,15], and $T_{3}$ retards spontaneous metamorphosis [29]. These $\mathrm{KClO}_{4}$ treatment studies were conducted at nonseasonal, warm, water temperatures $\left(16-20^{\circ} \mathrm{C}\right)$ in the winter months when spontaneous metamorphosis does not occur. The effects of temperature on the induction process have not been investigated.

The primary objective of the current study was to determine if warm water is required for $\mathrm{KClO}_{4}$ treatment to induce metamorphosis. Another goal was to investigate the effects of warm and cold water conditions in the presence and absence of $\mathrm{KClO}_{4}$ on serum $\mathrm{TH}$ concentrations.

\section{Materials and methods}

Larval sea lampreys (Petromyzon marinus) greater than $120 \mathrm{~mm}$ in length were collected from Putnam Creek, New York in June 1995 and housed at a temperature of approximately $11^{\circ} \mathrm{C}$ at the University of Toronto at Scarborough [15]. On October 10, larval sea lampreys were removed in groups of five from a holding tank (without substrate) containing 150 individuals. The lengths and masses of these larvae were recorded, and larvae were assigned to one of four experimental aquaria $(211 ; 40 \times 20 \times 25 \mathrm{~cm})$ until each aquarium contained 10 larvae. Aquaria were maintained static (not on a flow-through system), and contained 121 of dechlorinated tap water and 6-7 cm of industrial sand for substrate. Water in the experimental aquaria was aerated and all aquaria were maintained on a $15-\mathrm{h}$ light, 9-h dark photoperiod throughout the study. Each aquarium was assigned one of four experimental groups: untreated cold water (untreated cold); untreated warm water (untreated warm); potassium perchlorate $\left(\mathrm{KClO}_{4}\right)$-treated cold water $\left(\right.$ cold $\left.\mathrm{KClO}_{4}\right)$; or $\mathrm{KClO}_{4}$-treated warm water (warm $\mathrm{KClO}_{4}$ ). Animals and experimental groups were randomly assigned to aquaria by lottery. Larvae were left undisturbed in their new environment for 1 day prior to any change in temperature and 8 days prior to the addition of $\mathrm{KClO}_{4}$. Water temperature in the cold water groups was gradually lowered by approximately $2^{\circ} \mathrm{C}$ per day until a temperature of $3^{\circ} \mathrm{C}$ was attained [typical winter temperatures for Putnam Creek $\left(1-4^{\circ} \mathrm{C}\right)$; J.E. Gersmehl, pers. commun.]. Cold water temperatures were achieved using a circulating water chiller (Frigid Units) to regulate the water temperature in a large insulated tank which was used as a bath to maintain the temperature of the experimental aquaria. Water temperature in the warm water groups was maintained at ambient room temperature $\left(16-20^{\circ} \mathrm{C}\right)$. The experiment was initiated on October 17 , when $500 \mathrm{ml}$ of a $\mathrm{KClO}_{4}$ stock solution was added to the warm and cold $\mathrm{KClO}_{4}$ aquaria to achieve a final concentration of $3.6 \mathrm{mM}(0.05 \%)$.

The instantaneous water temperature in each of the untreated aquaria was recorded twice daily, larvae were fed $100 \mathrm{ml}$ of a Fleischmann's baker's yeast solution equal to $1 \mathrm{~g}$ of yeast/animal per week [12], and water was added to the aquaria as needed to keep the total volume at $12 \mathrm{l}$. Aquaria were cleaned, the water was changed, and fresh treatments were added every 2 weeks without disturbing the burrowed larvae. The accumulation of waste products, e.g. ammonia, was not determined throughout the course of the experiment. Spent larvae were replaced using animals marked with a latex dye injected into the caudal sinus; marked animals were excluded from all analyses. Eight weeks from the onset of the study all sea lampreys were anesthetized in a solution of $0.05 \%$ tricaine methanesulfonate and examined for external signs of the seven stages (1 to 7) of metamorphosis [25]. The experiment was terminated 23 weeks from its onset at which time sea lampreys were anesthetized, their lengths, masses, and metamorphic stages were recorded and serum was collected [14].

Serum $\mathrm{T}_{4}$ and $\mathrm{T}_{3}$ concentrations were measured using the Amersham Amerlex TT4 and TT3 radioimmunoassay (RIA) kits, respectively. The kits were modified for sea lamprey serum TH concentrations and small working volumes [9]. All serum samples were assayed in duplicate; assay sensitivities were 7 and 0.4 nmol/1 for $\mathrm{T}_{4}$ and $\mathrm{T}_{3}$, respectively, and intra- and inter-assay variances were 9.4 and $11.8 \%$ for $\mathrm{T}_{4}$, and 7.2 and $12.9 \%$ for $\mathrm{T}_{3}$, respectively.

Differences in animal length and mass, and serum $T_{4}$ and $T_{3}$ concentrations between aquaria (groups) were tested for statistical significance using analysis of variance (ANOVA) and Tukey's HSD multiple comparison test. Prior to ANOVA analyses, all data were tested for heteroscedasticity of variances using Cochran's $Q$-test. Data which did not meet the assumption of homoscedasticity were transformed $\left(\log _{10}\right)$; subsequent to transformation all data satisfied this assumption [19]. All statistical calculations were performed using Statistix for Microsoft DOS, data are presented as mean \pm 2 S.E., and all differences were considered statistically significant if $P<0.05$.

\section{Results}

Mean water temperatures in warm and cold water aquaria were $18 \pm 0.17$ and $3 \pm 0.07^{\circ} \mathrm{C}$, respectively. The mean length and mass of all larval sea lampreys at the onset of the study were $138 \pm 4 \mathrm{~mm}$ and $3.89 \pm 0.38$ $\mathrm{g}$, respectively, and these size parameters did not differ significantly among groups. Additionally, significant differences in animal length and mass were not ob- 
served among the groups at the termination of the experiment when the overall mean animal size was $137 \pm 4 \mathrm{~mm}$ and $3.70 \pm 0.37 \mathrm{~g}$.

Eight weeks from the onset of the study, metamorphosis was not observed in larvae from the untreated warm, untreated cold, or cold $\mathrm{KClO}_{4}$ experimental groups. However, at this time $80 \%$ of the warm $\mathrm{KClO}_{4}$ larvae had commenced metamorphosis. Five animals were determined to be in stage 1 of metamorphosis, three in stage 2 of metamorphosis, and the remaining two individuals were larvae. At the end of the study (following 23 weeks of treatment), metamorphosis was still not observed in any untreated or cold $\mathrm{KClO}_{4}$ larvae. There had been some mortality of unknown causes in the warm $\mathrm{KClO}_{4}$ experimental group but all surviving (8/8) animals had commenced metamorphosis (Fig. 1). Of these metamorphosing individuals, one was described to be at stage 1, two between stages 3 and 4 , one at stage 4 , three at stage 5 , and one at stage 6 of metamorphosis. Warm $\mathrm{KClO}_{4}$ larvae were clearly undergoing metamorphosis, but the timing and morphology of $\mathrm{KClO}_{4}$-induced development was asynchronous. In several individuals the eyes, teeth, and/or body coloration had undergone changes in advance of structures such as the oral disc and branchiopores. In spontaneous metamorphosis the changes in the morphology of these structures are highly synchronized within and among individuals [25].

Serum $\mathrm{T}_{4}$ and $\mathrm{T}_{3}$ concentrations of untreated larvae were not significantly affected by temperature. Mean serum concentrations were 92 and $100 \mathrm{nmol} / 1$ for $\mathrm{T}_{4}$, and 23.7 and $27.6 \mathrm{nmol} / 1$ for $\mathrm{T}_{3}$ in the untreated warm and cold larvae, respectively (Fig. 2). Similarly, serum

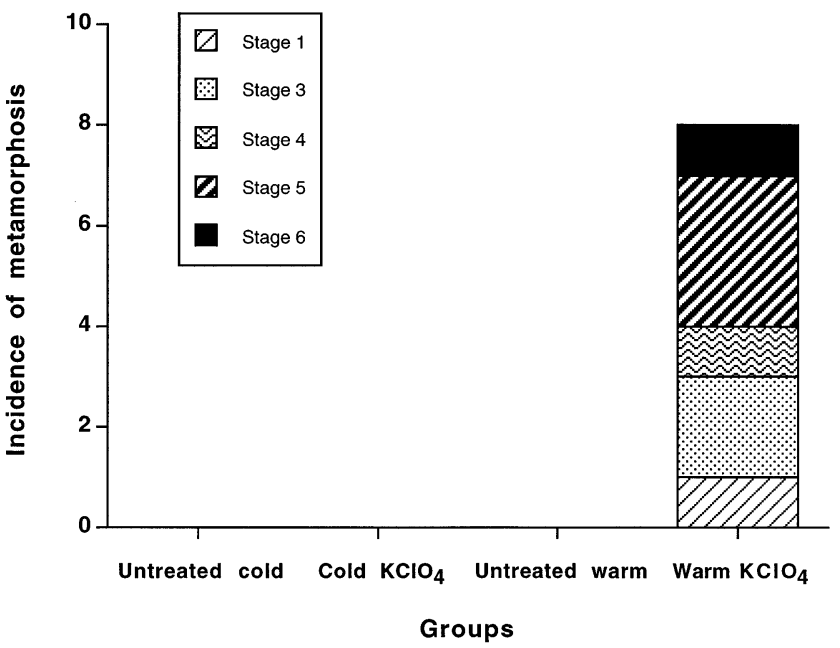

Fig. 1. Stage and incidence of metamorphosis in untreated and potassium perchlorate $\left(\mathrm{KClO}_{4}\right)$-treated larval sea lampreys (Petromyzon marinus $)$ at warm $\left(18^{\circ} \mathrm{C}\right)$ and cold $\left(3^{\circ} \mathrm{C}\right)$ water temperatures after 23 weeks. Metamorphosing sea lampreys which were between stages were assigned the earlier of the two stages. Sample size $(N)$ is 10 for all groups with the exception of the warm $\mathrm{KClO}_{4}$ group where $N=8$.

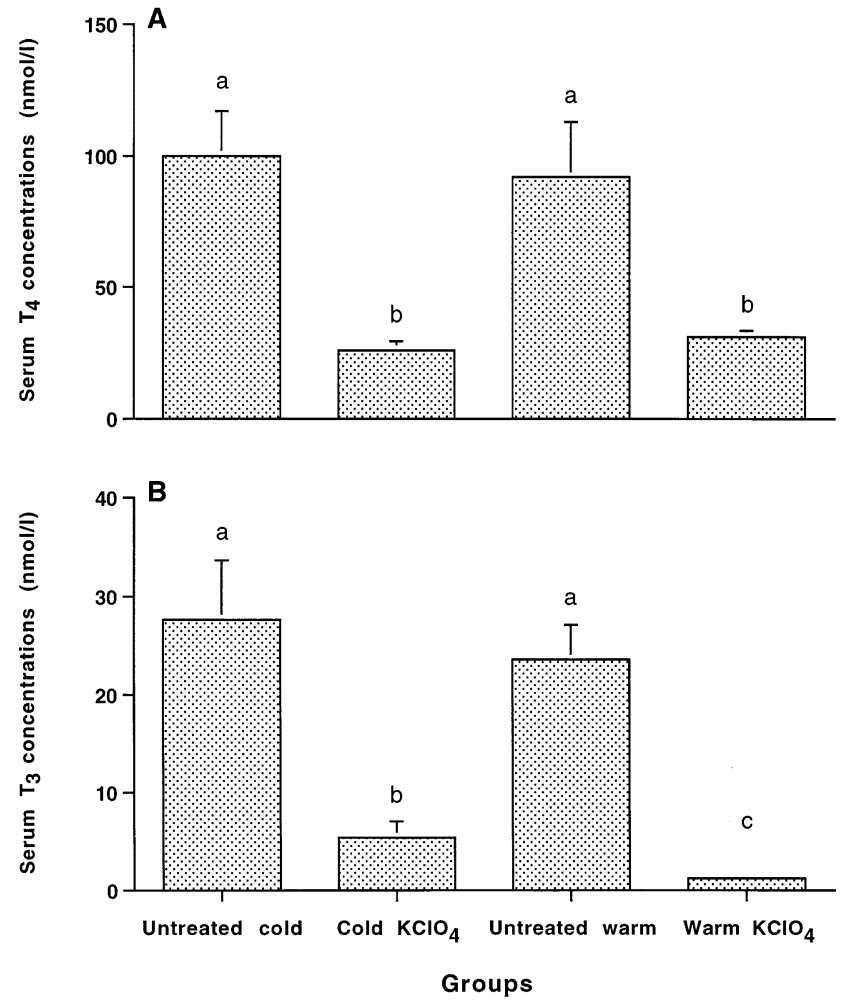

Fig. 2. Mean ( \pm 2 S.E.) serum thyroxine $\left(\mathrm{T}_{4} ; \mathrm{A}\right)$ and 3,5,3'-triiodothyronine $\left(\mathrm{T}_{3} ; \mathrm{B}\right)$ concentrations in untreated and potassium perchlorate $\left(\mathrm{KClO}_{4}\right)$-treated larval sea lampreys at warm $\left(18^{\circ} \mathrm{C}\right)$ and cold $\left(3^{\circ} \mathrm{C}\right)$ water temperatures after 23 weeks. Differences in serum $\mathrm{T}_{4}$ and $\mathrm{T}_{3}$ concentrations between groups are statistically significant $(P<0.05)$ if labeled with different letters. Sample size $(N)$ is 10 for all groups with the exception of the warm $\mathrm{KClO}_{4}$ group where $N=8$.

$\mathrm{T}_{4}$ was not affected by temperature in the presence of $\mathrm{KClO}_{4}$; mean concentrations were 31 and $26 \mathrm{nmol} / 1$ for the warm and cold $\mathrm{KClO}_{4}$ groups, respectively (Fig. 2A). However, $\mathrm{KClO}_{4}$ treatment significantly depressed serum $\mathrm{T}_{4}$ concentrations in both warm and cold $\mathrm{KClO}_{4}$ larvae relative to untreated warm and cold larvae. Warm and cold $\mathrm{KClO}_{4}$ larvae had serum $\mathrm{T}_{4}$ concentrations 66 and $73 \%$ lower than their respective untreated warm and cold larvae. $\mathrm{KClO}_{4}$ treatment also significantly depressed serum $\mathrm{T}_{3}$ concentrations in both warm and cold $\mathrm{KClO}_{4}$ larvae relative to untreated warm and cold larvae. Serum $\mathrm{T}_{3}$ concentrations in warm and cold $\mathrm{KClO}_{4}$ larvae were 95 and $80 \%$ lower than untreated warm and cold larvae, respectively. Furthermore, mean serum $\mathrm{T}_{3}$ concentrations in warm $\mathrm{KClO}_{4}$ larvae $(1.2$ $\mathrm{nmol} / \mathrm{l})$ were significantly lower than in cold $\mathrm{KClO}_{4}$ larvae (5.4 nmol/1; Fig. 2B).

\section{Discussion}

The goitrogen $\mathrm{KClO}_{4}$ induces precocious metamorphosis and a concomitant decline in serum TH concentrations in larval sea lampreys $[6,14,15,28]$. The 
aforementioned studies controlled for temperature and time of year; they were conducted during the winter months at warm (summer) water temperatures (16$20^{\circ} \mathrm{C}$ ). In the current study, larval sea lampreys were exposed to either a warm or cold water temperature (equivalent to summer and winter conditions, respectively) in the presence or absence of $\mathrm{KClO}_{4}$; the experiment was conducted at a time of year when spontaneous metamorphosis is not expected. Exposure of larvae to $\mathrm{KClO}_{4}$ at warm water temperatures significantly depressed serum TH concentrations and induced metamorphosis in $100 \%$ of all surviving individuals; mortality was due to causes seemingly unrelated to the treatment. These results with $\mathrm{KClO}_{4}$ treatment at a warm water temperature are similar to those of earlier studies $[6,14,15,28]$. However, $\mathrm{KClO}_{4}$ treatment at a cold water temperature did not induce metamorphosis in any larvae despite significant declines in both serum $\mathrm{T}_{4}$ and $\mathrm{T}_{3}$ concentrations. The absence of metamorphosis in cold $\mathrm{KClO}_{4}$ larvae further emphasizes the importance of water temperature in the initiation of lamprey metamorphosis and indicates that a decrease in serum $\mathrm{TH}$ concentrations is not sufficient to induce metamorphosis. $\mathrm{T}_{3}$-induced metamorphosis in amphibians is also temperature-dependent. Frieden et al. [5] and Ashley et al. [1] found no change in frog tail length or urea production, respectively, following $\mathrm{T}_{3}$ treatment at $5^{\circ} \mathrm{C}$ but responses were detected at temperatures $\geq 7.5^{\circ} \mathrm{C}$.

Serum $\mathrm{T}_{3}$ concentrations in warm $\mathrm{KClO}_{4}$ larvae were significantly lower than serum $\mathrm{T}_{3}$ values in cold $\mathrm{KClO}_{4}$ larvae; furthermore, the magnitude of the declines in serum $T_{3}$ concentrations from values in respective untreated larvae were greater for warm $\mathrm{KClO}_{4}$ larvae $(95 \%)$ than cold $\mathrm{KClO}_{4}$ larvae $(80 \%)$. Despite the differences in serum $\mathrm{T}_{3}$ concentrations between warm and cold $\mathrm{KClO}_{4}$ larvae, it is not likely that these differences contributed to the absence of metamorphosis in cold $\mathrm{KClO}_{4}$ larvae. In two previous studies, metamorphosis was observed in larval sea lampreys treated with $\mathrm{KClO}_{4}$ at a warm water temperature in which serum $\mathrm{T}_{3}$ concentrations were only $72-77 \%$ lower than values for untreated control larvae [14,15]; these declines in serum $\mathrm{T}_{3}$ levels are similar to those observed in cold $\mathrm{KClO}_{4}$ larvae of the current study. Thus, the absence of metamorphosis in cold $\mathrm{KClO}_{4}$ larvae may have been a result of the effects of the cold water temperature on regulatory processes of metamorphosis other than serum $\mathrm{TH}$ concentrations.

Many biological processes essential to life in poikilotherms are dependent either directly or indirectly on environmental temperature which has been shown to alter both basal metabolic rate and the rate at which developmental processes proceed [2]. In lampreys, it has been established that metabolic rate (measured as oxygen consumption) decreases with decreasing temperature $[10,18]$. Cold water temperatures may reduce the metabolic rate in lampreys below a minimum required for metamorphosis or may simply reduce the rate of metamorphic development.

We have previously shown that $\mathrm{KClO}_{4}$ treatment at warm water temperatures does not affect intestinal $\mathrm{T}_{4}$ outer-ring $\left(5^{\prime}\right)$ deiodination to $\mathrm{T}_{3}\left(\mathrm{~T}_{4} \mathrm{ORD}\right)$, the primary site and deiodination pathway, in larval sea lampreys [15]. However, it has been shown that changes in deiodinase activity coincide with changing developmental and/or physiological state in lampreys $[3,4]$. Although $\mathrm{KClO}_{4}$ treatment at warm water temperatures did not alter intestinal $\mathrm{T}_{4} \mathrm{ORD}$ activity [15], perhaps the activities of this or other deiodinase pathways were sufficiently altered in cold $\mathrm{KClO}_{4}$ larvae of the current study to prevent the induction of metamorphosis. Temperature has been shown to affect TH deiodinase activity in rainbow trout [7]. Furthermore, Kaltenbach [8] posed the question: Does temperature alter the number of $\mathrm{TH}$ receptors in anurans? Could this question also apply to lampreys? Future research should be directed towards elucidating the function of the $\mathrm{TH}$ deiodinase pathways and $\mathrm{TH}$ receptors in metamorphosis and their responses to temperature change.

The initiation of lamprey metamorphosis occurs when a number of physiological and environmental requirements are met [23]. $\mathrm{KClO}_{4}$ depresses serum $\mathrm{TH}$ concentrations and can override some of these requirements such as size, condition factor, essential fat stores, and thyroid status resulting in the induction of metamorphosis [24]. However, water temperature is a very important cue in lamprey metamorphosis which cannot be eliminated from the sequence of events involved in the initiation of this developmental process.

\section{Acknowledgements}

This study was supported by a Natural Sciences and Engineering Grant (OPG-5945) to J.H. Youson. The authors wish to thank Lori Manzon and Preshi Shanmugathansan for their assistance with sea lamprey collection and serum analysis, respectively, and John Gersmehl (US Fish and Wildlife Service, Essex Junction, VT) for sharing his expertise on Putnam Creek and sea lamprey collection.

\section{References}

[1] Ashley H, Katti P, Frieden E. Urea excretion in the bullfrog tadpole: Effect of temperature, metamorphosis, and thyroid hormones. Dev Biol 1968;17:293-307.

[2] Brett JR. Some principles in the thermal requirements of fishes. Q Rev Biol 1956;31:75-87.

[3] Eales JG, Holmes JA, McLeese JM, Youson JY. Thyroid hormone deiodination in various tissues of larval and upstream-migrant sea lampreys, Petromyzon marinus. Gen Comp Endocrinol 1997;106:202-10. 
[4] Eales JG, McLeese JM, Holmes JA, Youson JY. Changes in intestinal and hepatic thyroid hormone deiodination during spontaneous metamorphosis of the sea lamprey, Petromyzon marinus, J Exp Zool 1999, in press.

[5] Frieden E, Wahlborg A, Howard E. Temperature control of the response of tadpoles to triiodothyronine. Nature 1965;205:11736.

[6] Holmes JA, Youson JH. Induction of metamorphosis in landlocked sea lampreys, Petromyzon marinus. J Exp Zool 1993;267:598-604.

[7] Johnston CE, Eales JG. Effects of acclimation and assay temperature on outer- and inner-ring thyroxine and 3,5,3'-triiodo-L-thyronine deiodination by liver microsomes of rainbow trout, Oncorhynchus mykiss. J Exp Zool 1995;272:426-34.

[8] Kaltenbach JC. Endocrinology of amphibian metamorphosis. In: Gilbert LI, Tata JR, Atkinson BG, editors. Metamorphosis: Postembryonic Reprogramming of Gene Expression in Amphibian and Insect Cells. New York: Academic Press, 1996:403-31.

[9] Leatherland JF, Hilliard RW, Macey DJ, Potter IC. Changes in serum thyroxine and triiodothyronine concentrations during metamorphosis of the Southern Hemisphere lamprey Geotria australis, and the effect of propylthiouracil, triiodothyronine and environmental temperature on serum thyroid hormone concentrations of ammocoetes. Fish Physiol Biochem 1990;8:167-77.

[10] Lewis SV. Respiration of lampreys. Can J Fish Aquat Sci 1980;37:1711-22.

[11] Lintlop SP, Youson JH. Concentration of triiodothyronine in the sera of the sea lamprey, Petromyzon marinus, and the brook lamprey, Lampetra lamottenii, at various phases of the life cycle. Gen Comp Endocrinol 1983;49:187-94.

[12] Mallatt J. Laboratory growth of larval lampreys (Lampetra (Entosphenus) tridentata Richardson) at different food concentrations and animal densities. J Fish Biol 1983;22:293-301.

[13] Manion PJ, Stauffer TM. Metamorphosis of the landlocked sea lamprey, Petromyzon marinus. J Fish Res Bd Can 1970;27:173546.

[14] Manzon RG, Youson JH. The effects of exogenous thyroxine $\left(\mathrm{T}_{4}\right)$ or triiodothyronine $\left(\mathrm{T}_{3}\right)$, in the presence and absence of potassium perchlorate, on the incidence of metamorphosis and on serum $\mathrm{T}_{4}$ and $\mathrm{T}_{3}$ concentrations in larval sea lampreys (Petromyzon marinus L.). Gen Comp Endocrinol 1997;106:21120.

[15] Manzon RG, Eales JG, Youson JH. Blocking of $\mathrm{KClO}_{4}$-induced metamorphosis in premetamorphic sea lampreys by exogenous thyroid hormones (TH); effects of $\mathrm{KClO}_{4}$ and $\mathrm{TH}$ on serum $\mathrm{TH}$ concentrations and intestinal thyroxine outer-ring deiodination. Gen Comp Endocrinol 1998;112:54-62.
[16] Potter IC. The life cycles and ecology of Australian lampreys of the genus Mordacia. J Zool Lond 1970;161:487-511.

[17] Purvis HA. Effects of temperature on metamorphosis and the age and length at metamorphosis in sea lamprey (Petromyzon marinus) in the Great Lakes. Can J Fish Aquat Sci 1980;37:1827-34.

[18] Randall DJ. Respiration. In: Hardisty MW, Potter IC, editors. Biology of Lampreys, vol. 2. New York: Academic Press, 1972:287-306

[19] Sokal RR, Rohlf FJ. Biometry. San Francisco, CA: W.H. Freeman, 1981.

[20] Wright GM, Youson JH. Serum thyroxine concentrations in larval and metamorphosing anadromous sea lamprey, Petromyzon marinus L. J Exp Zool 1977;202:27-32.

[21] Youson JH. Morphology and physiology of lamprey metamorphosis. Can J Fish Aquat Sci 1980;37:1687-710.

[22] Youson JH. First metamorphosis. In: Hoar WS, Randall DJ, editors. Fish Physiology, vol. XIB. New York: Academic Press, 1988:135-96.

[23] Youson JH. Environmental and hormonal cues and endocrine glands during lamprey metamorphosis. In: Davey KG, Peter RE, Tobe SS, editors. Perspectives in Comparative Endocrinology. Ottawa, ON: National Research Council of Canada Publications, 1994:400-7.

[24] Youson JH. Is lamprey metamorphosis regulated by thyroid hormones? Am Zool 1997;37:441-60.

[25] Youson JH, Potter IC. A description of the stages in the metamorphosis of the anadromous sea lamprey, Petromyzon marinus L. Can J Zool 1979;57:1808-17.

[26] Youson JH, Holmes JA, Guchardi JA, Seelye JG, Beaver RE, Gersmehl JE, Sower SA, Beamish FWH. Importance of condition factor and the influence of water temperature and photoperiod on metamorphosis of sea lamprey, Petromyzon marinus. Can J Fish Aquat Sci 1993;50:2448-56.

[27] Youson JH, Plisetskaya EM, Leatherland JF. Concentrations of insulin and thyroid hormones in the serum of landlocked sea lampreys (Petromyzon marinus) of three larval year classes, in larvae exposed to two temperature regimes, and in individuals during and after metamorphosis. Gen Comp Endocrinol 1994;94:294-304.

[28] Youson JH, Holmes JA, Leatherland JF. Serum concentrations of thyroid hormones in $\mathrm{KClO}_{4}$-treated larval sea lampreys (Petromyzon marinus L.). Comp Biochem Physiol 1995;111:26570.

[29] Youson JH, Manzon RG, Peck BJ, Holmes JA. Effects of exogenous thyroxine $\left(T_{4}\right)$ and triiodothyronine $\left(T_{3}\right)$ on spontaneous metamorphosis and serum $\mathrm{T}_{4}$ and $\mathrm{T}_{3}$ levels in immediately premetamorphic sea lampreys, Petromyzon marinus. J Exp Zool 1997;279:145-55. 